\title{
The Effectiveness of Electronic Supervision for Supervisee Groups in the School Field
}

\section{Mohamed Mohamed Selem Ahmed (PhD)}

Associate Professor, Group Work Department Faculty of Social Work - Helwan University 


\section{Abstract}

This study aims to determine the effectiveness of electronic supervision for supervisee groups in the school field. This study applies the descriptive and analytical approaches; it uses social survey as a method for collecting social data through questionnaires Moreover, it is applied on social workers working in schools within Muscat Governorate of Oman, during the period from September 2020 until November 2020. The results show the importance of electronic supervision and indicates a variety of roles for electronic supervision in the school field. Finally, the present study demonstrates that electronic supervision must be activated with supervisee groups in the school field.

Keywords: effectiveness - electronic supervision - group supervision Introduction:

Modern technologies represented in the internet, computers, smart devices, and other technological means are one of the most successful media that provide an integrated and attractive educational environment at the same time. Furthermore, they enable to connect people of all ages and businesses at anytime and anywhere with minimal effort, time and cost. Relying on these modern technologies makes a remarkable development in the school environment by working to promote them in all its components and elements to achieve its goals and objectives (Al-Daihani, Al-Khazzi, \& Al-Jadi, 2016, p. 310).

Thus, "technology has transformed the nature of social work education. Whether it is used to supplant or supplement face-to-face instruction, social worker educators must keep pace with rapidly developing standards of practice and related ethical standards"(Reamer, 2019). Therefore, we must work to prepare students of social work who commensurate with the requirements of the modern era. This requires a review of the field training process so that technological means are employed to achieve the quality of professional preparation.

This is confirmed by Reamer (2019), who provides an overview of the new standards, especially ones related to the diverse ways in which technology is being used in social work education, instructor competence, academic standards, and field education. He explores the new standards' broad implications for contemporary social work education in the digital age (pp. 420-432). 
Therefore, "social work supervision can and should be viewed from a holistic perspective. It is practiced in a multifaceted context. It is an intensive, interactional, and interpersonal process involving two professional parties who are accountable to the agency and the client" (Tsui, 2005, p. 61). This is consistent with one of the articles by O’Donoghue, Wong Yuh (2018), which refers to "proposed evidenceinformed model of social work supervision consists of five key areas, namely, the construction of social work supervision, supervision of the practitioner, the supervision alliance, the interactional process and the supervision of direct practice" (pp. 348-358).

This is corroborative by another study by O'Donoghue, (2015), which provides a theory about social work supervision to advance social work supervision theory and practice. Therefore, the research aims to: (i) focus on evaluating the effectiveness of supervision practices across all of the various formats in order to develop empirically supported supervision practice models; (ii) discover how supervision practice contributes to client out-comes and involves clients in supervision research; and (iii) develop an inter- national understanding of nature and practice of supervision (p. 628).

Another study by Ricciardelli, Nackerud, Quinn, Sewell\& Casiano (2020), reveals that social work students seemingly hold conflicting attitudes toward social media that are also at times contrary to their self-reported knowledge and use of social media. The authors discuss social media's ethical implications for the social work profession, taking the position that information about social media should be included in the social work curricula.

This requires the necessity of dealing with the challenges associated with the virtual world and overcoming them through ethical commitment in all stages of supervisory work, and this is indicated in another article by O'Donoghue,\& O'Donoghue, (2019), which provide a selective review of social work supervision and ethics literature. This article proposes that ethics should be integrated throughout the supervision process through the development of care ethics culture, ethical sensitivity and ethical dialogue (pp. 340-360).

It can also be dealt with challenges through supervisor's experience and ability to help their supervisees, and this is shown in one developmental article (Fareez, 2019), which indicates that "supervisor life certificate is a tool which helps social workers reflect on the values that they bring to their supervisory roles" (pp. 64-73). 
Moreover, Fisher, Simmons, \& Allen (2019) propose some recommendations for social work educators related to the need for educators to provide information on the use of supervision for BSW students, the necessity for guiding student reflections as part of the supervision exercises and considering the developmental levels of students when crafting educational interventions (pp. 1085-1102).

In addition, Rankine (2019) views that the process of thinking aloud supports the opportunity and space for the supervisor and supervisee to articulate meaning, critically develop insight, reconstruct, and transport this into future practice. Thinking aloud offers an example of how knowledge can be co-constructed by practitioners within practice and critical reflection captured within qualitative research approaches (pp. 97-110).

It should also be noted that growing interest for the subject of electronic supervision in the light of the rapid changes within information communication technology, and the emergence of new concepts and tools for information technology, such as free Google tools available on all computers and smart phones, which allows creating electronic documents and questionnaires, conducting electronic examinations, and the emergence of second and third generation social media allowing the exchange of various educational files and videos that serve the educational learning process with all its parties and spectrums (Al-Azamat, 2020, p. 3).

This is confirmed in one developmental study (fath albab, 2016), which finds out "proposed plan in the e-training for groups of social work students, and she also emphasizes a variety of electronic techniques according to the nature and content of the electronic training program" (pp. 361 - 395).

\section{The study problem is thus focused on responding to the questions:}

1. What are the types of training suitable for electronic supervision in the school field?

2. What are the tools employed in electronic supervision in the school field?

3. What are the roles of the supervisor with supervisee groups regarding electronic supervision in the school field?

4. What are the difficulties facing the supervisor with supervisee groups in electronic supervision in the school field?

5. What are the suggestions for activating electronic supervision with supervisee groups in the school field? 


\section{Importance of the Study:}

1. The study deals with the subject of electronic supervision, whose importance increases during the Corona pandemic (COVID-19).

2. The training field process and its development is one of the focal issues in social work.

3. Group work method needs to dilate the knowledge base of electronic supervision.

\section{Study Objectives:}

1. Determining the types of training suitable for electronic supervision in the school field.

2. Determining the tools employed in electronic supervision in the school field.

3. Determining the roles of the supervisor with supervisee groups regarding electronic supervision in the school field.

4. Determining the difficulties facing the supervisor with supervisee groups in electronic supervision in the school field.

5. Reaching the suggestions for activating electronic supervision with supervisee groups in the school field.

Study Hypotheses: The current research attempts to examine the following hypotheses:

First Hypothesis: There is a statistically significant correlation between types of training suitable in electronic supervision for male and female.

Second Hypothesis: There is a statistically significant correlation between the roles of the supervisor with supervisee groups and the tools for electronic supervision in the school field.

\section{Study Concepts:}

\section{Effectiveness:}

Munir Al-Baalbaki (1997) states that the concept of effectiveness means in the brief dictionary the ability of a thing to influence, and it is defined in the Al Mourid dictionary as the ability to influence or be effective or sufficient, and effectiveness is also defined as the degree to accomplish goals (Mohamed, 2020, p. 398).

\section{Electronic supervision:}

"A supervisory style can be provide training programs and known supervisory styles through a variety of electronic means such as using the computer, the internet and its tools in a synchronized or asynchronous method, relying on the principle of self-supervision" (Al-Azamat, 2020, pp. 4-5). 
We should remember that the supervision process must be creative, engaging, enabling, and ensuring. New ideas should be encouraged and acknowledged. Both the supervisor and the supervisee can learn and grow. Supervision should also be a process that makes supervisees feel that they belong to an organization. The staff should feel that they are directly engaged with their client and with the organization (Tsui, 2005, p. 136).

Electronic supervision is "a model based on the proper integration of technology, to replace traditional supervision, using several methods, including: e-mails, discussion boards, forums, phone calls, and chat rooms that take place synchronously or asynchronously, through three basic elements that include users, infrastructure, Methods and methods" (Al-Azamat, 2020, p. 5)

Electronic supervision concepts mean practicing supervisory styles that depend on modern communication techniques to support social workers and develop them professionally.

\section{Group supervision:}

refers to "a wide range of activities, including planning meetings, team meetings, and case conferences. Group super-vision uses a group setting and a group process to implement the functions of supervision, i.e., administrative, educational, and supportive" (Tsui, 2005, p. 118) .

Group supervision is thus seen to provide a forum for supervision where issues of practice can be considered within an accountable framework and where intrapersonal awareness and interpersonal relationships can be developed. It is also where a breadth of understanding and skill can emerge around practice and practice contexts and where interactive ways of exploring practice can be utilized (Beddoe, 2016, p. 125).

\section{Methodological Procedures:}

This study belongs to the descriptive and analytical studies to determine the characteristics of a specific problem and examine its surrounding conditions. It uses social survey as a method for collecting social data through questionnaires, and it is applied on social workers working in schools within Muscat Governorate of Oman, within the period from September 2020 until November 2020.

\section{population:}

- The population includes all social workers in schools in Muscat, and their number is 154 social workers (51 males, 103 females). 
- This study targets all social workers, but the number collected is 78 social workers because of the difficulty to reach them during Coronavirus pandemic (COVID-19).

\section{Study Tools:}

This study relies on a questionnaire which is divided into six axes: Part one: the Basic data, Part two: the types of training suitable for electronic supervision in the school field, Part three: the tools employed in electronic supervision in the school field, Part four: the roles of the supervisor with supervisee groups regarding electronic supervision in the school field, Part five: the difficulties facing the supervisor with supervisee groups in electronic supervision in the school field, Part six: the suggestions for activating electronic supervision with supervisee groups in the school field.

Validity: The questionnaire is administered to five social work experts to judge the questionnaires and express their opinion about the appropriateness of each statement regarding its formulation and its relevance to the dimension to be measured. They were free to add suitable statements, delete other statements and modify some statements regarding the formulation. Answers to each statement are presented by selecting one of the three answers (I agree- somewhat agree - do not agree).

Reliability: The coefficient of stability Alpha-Cronbach is used to ensure Reliability, and its outcome $=0.894$. This result indicates an acceptable degree of reliability; therefore, this tool can be relied upon.

\section{Results}

\section{Table (1) shows gender $(\mathrm{N}=78)$}

\begin{tabular}{|c||c||c||c||}
\hline $\mathrm{N}$ & Gender & Frequency & Percent \\
\hline \hline 1 & Male & 26 & 33.3 \\
\hline \hline 2 & Female & 52 & 66.7 \\
\hline \hline \multicolumn{2}{|c|}{ Total } & 78 & 100 \\
\hline \hline
\end{tabular}

This table shows gender which indicates that the largest percentage was for females with $66.7 \%$ and for the male with a percentage of $33.3 \%$ Table (2) shows ages $(\mathrm{N}=78)$

\begin{tabular}{|c|c|c|c|}
\hline$\overline{\mathrm{N}}$ & Age & Frequency & Percent \\
\hline 1 & From 25 - to less than 35 years & 13 & 16.7 \\
\hline 2 & From 35 - to less than 45 years & 42 & 53.8 \\
\hline 3 & 45 years or more & 23 & 29.5 \\
\hline & 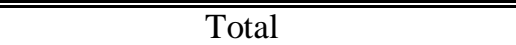 & $\overline{78}$ & 100 \\
\hline
\end{tabular}

This table shows ages which indicates the largest percentage is "From 35 - to less than 45 years " with percentage of $53.8 \%$, as for 


\begin{tabular}{|lr||}
\hline Egyptian Journal of Social Work (EJSW) & http://ejsw.journals.ekb.eg \\
ISSN: 2356-9204 & Vol 12, Issue 1, June 2021 \\
\hline
\end{tabular}

" 45 years or more " with percentage of $29.5 \%$, and " From 25 - to less than 35 years " with percentage of $16.7 \%$

Table (3) shows duration of experience $(\mathrm{N}=78)$

\begin{tabular}{|c|c|c|c|}
\hline $\mathrm{N}$ & Experience & Frequency & Percent \\
\hline 1 & From 5 - to less than 10 years & 15 & 19.2 \\
\hline 2 & From 10 - to less than 15 years & 31 & 39.7 \\
\hline 3 & 15 years or more & 32 & 41 \\
\hline & Total & 78 & 100 \\
\hline
\end{tabular}

This table shows duration of experience which enables the social worker to perform his professional roles in social work, also these experiences help him to adhere to the requirements of the supervisory process. The table indicates that their experience was "15 years or more" with percentage of $41 \%$, as for "From 10 - to less than 15 years" with percentage of $39.7 \%$ and "From 5 - to less than 10 years" with percentage of $19.2 \%$.

Table (4) shows the types of training suitable for electronic supervision in the school field $(\mathrm{N}=78)$

\begin{tabular}{|c|c|c|c|c|c|c|c|c|c|c|c|}
\hline \multirow[b]{3}{*}{$\mathrm{N}$} & \multirow{3}{*}{$\begin{array}{l}\text { Types of } \\
\text { training } \\
\text { suitable for } \\
\text { electronic } \\
\text { supervision }\end{array}$} & \multicolumn{6}{|c|}{ Responses } & \multirow{3}{*}{$\begin{array}{l}\frac{0}{0} \\
\frac{0}{0} \\
0 \\
\frac{\pi}{0} \\
0\end{array}$} & \multirow{3}{*}{ 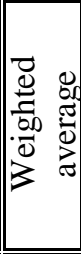 } & \multirow{3}{*}{ 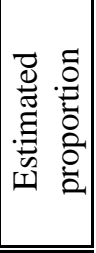 } & \multirow{3}{*}{ 堷 } \\
\hline & & \multicolumn{2}{|c|}{ yes } & \multicolumn{2}{|c|}{ sometimes } & \multicolumn{2}{|c|}{ no } & & & & \\
\hline & & 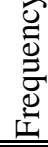 & $\%$ & 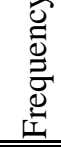 & $\%$ & 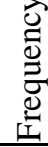 & $\%$ & & & & \\
\hline 1 & $\begin{array}{l}\text { Synchronous } \\
\text { training } \\
\text { through the } \\
\text { World Wide } \\
\text { Web } \\
\end{array}$ & 20 & 25.6 & 33 & 42.3 & 25 & 32.1 & 151 & 1.9 & 64.5 & 3 \\
\hline 2 & $\begin{array}{l}\text { Training is not } \\
\text { synchronized } \\
\text { through the } \\
\text { World Wide } \\
\text { Web }\end{array}$ & 36 & 46.2 & 40 & 51.3 & 2 & 2.6 & 190 & 2.4 & 81.2 & 1 \\
\hline 3 & $\begin{array}{l}\text { Mixed training } \\
\text { between } \\
\text { synchronous } \\
\text { and not } \\
\text { synchronous }\end{array}$ & 34 & 43.6 & 38 & 48.7 & 6 & 7.7 & 184 & 2.4 & 78.6 & 2 \\
\hline \multicolumn{2}{|c|}{ Total } & 90 & 38.5 & 111 & 47.4 & 33 & 14.1 & 525 & 2.2 & \multicolumn{2}{|c|}{74.8} \\
\hline
\end{tabular}

This table demonstrates the types of training suitable for electronic supervision in the school field which must be used to achieve the objectives of the training process such as "Training is not 


\begin{tabular}{|lr||}
\hline Egyptian Journal of Social Work (EJSW) & http://ejsw.journals.ekb.eg \\
ISSN: 2356-9204 & Vol 12, Issue 1, June 2021 \\
\hline
\end{tabular}

synchronized through the World Wide Web", which came in the first ranking with percentage of $81.2 \%$, as for the second ranking "Mixed training between synchronous and not synchronous" with percentage of $78.6 \%$, and the third ranking "Synchronous training through the World Wide Web" with percentage of $64.5 \%$.

Table (5) shows the tools employed in electronic supervision in the school field $(\mathrm{N}=78)$

\begin{tabular}{|c|c|c|c|c|c|c|c|c|c|c|c|}
\hline \multirow[b]{3}{*}{$\mathrm{N}$} & \multirow[b]{3}{*}{ The tools } & \multicolumn{6}{|c|}{ Responses } & \multirow{3}{*}{ 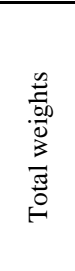 } & \multirow{3}{*}{ 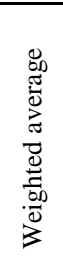 } & \multirow{3}{*}{ 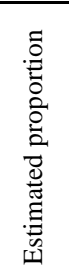 } & \multirow{3}{*}{ 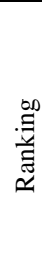 } \\
\hline & & \multicolumn{2}{|c|}{ yes } & \multicolumn{2}{|c|}{ sometimes } & \multicolumn{2}{|c|}{ no } & & & & \\
\hline & & 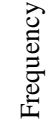 & $\%$ & 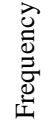 & $\%$ & 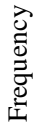 & $\%$ & & & & \\
\hline 1 & $\begin{array}{lr}\text { The } & \text { Internet } \\
\text { employed } & \text { in } \\
\text { supervisory work } & \end{array}$ & 48 & 61.5 & 30 & 38.5 & 0 & 0 & 204 & 2.6 & 87.2 & 4 \\
\hline 2 & $\begin{array}{ll}\text { Databases } & \text { that } \\
\text { facilitate access } & \text { to } \\
\text { training data } & \\
\end{array}$ & 51 & 65.4 & 27 & 34.6 & 0 & 0 & 207 & 2.65 & 88.5 & 2 \\
\hline 3 & $\begin{array}{l}\text { Websites, which are } \\
\text { electronic pages for } \\
\text { obtaining information } \\
\text { in training field }\end{array}$ & 40 & 51.3 & 33 & 42.3 & 5 & 6.4 & 191 & 2.4 & 81.6 & 5 \\
\hline 4 & $\begin{array}{l}\text { Electronic bags that } \\
\text { are prepared by } \\
\text { computer programs } \\
\text { about a specific topic }\end{array}$ & 52 & 66.7 & 25 & 32.1 & 1 & 1.3 & 207 & 2.65 & 88.5 & 2 \\
\hline 5 & $\begin{array}{lr}\text { Social } & \text { media } \\
\text { (WhatsApp - Twitter - } \\
\text { Instagram - Snapchat - } \\
\text {... etc.) }\end{array}$ & 62 & 79.5 & 14 & 17.9 & 2 & 2.6 & 216 & 2.77 & 92.3 & 1 \\
\hline & Total & 253 & 64.9 & 129 & 33.1 & 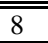 & 2.1 & 1025 & 2.63 & $\overline{87}$ & \\
\hline
\end{tabular}

This table signals the variety of tools for electronic supervision in the school field such as: "Social media (WhatsApp - Twitter Instagram - Snapchat - ... etc.) that came in the first ranking with percentage of $92.3 \%$, as for the second ranking "Databases that facilitate access to training data, and electronic bags that are prepared by computer programs about a specific topic" with percentage of $88.5 \%$, as for the fourth ranking "The Internet, employed in supervisory work" with percentage of $87.2 \%$, finally the fifth ranking "Websites, which are electronic pages for obtaining information in training field" with percentage of $81.6 \%$. 


\begin{tabular}{|ll|}
\hline $\begin{array}{l}\text { Egyptian Journal of Social Work (EJSW) } \\
\text { ISSN: 2356-9204 }\end{array}$ & http://ejsw.journals.ekb.eg \\
\hline Vol 12, Issue 1, June 2021 \\
\hline
\end{tabular}

Table (6) show the roles of the supervisor with supervisee groups regarding electronic supervision in the school field $(N=78)$

\begin{tabular}{|c|c|c|c|c|c|c|c|c|c|c|c|}
\hline \multirow[b]{3}{*}{$\mathrm{N}$} & \multirow{3}{*}{ The roles } & \multicolumn{6}{|c|}{ Responses } & \multirow{3}{*}{$\begin{array}{l}\frac{0}{0} \\
\frac{000}{0} \\
\frac{1}{3} \\
\frac{\pi}{0}\end{array}$} & \multirow{3}{*}{ 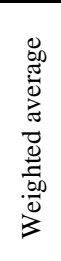 } & \multirow{3}{*}{ 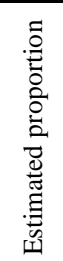 } & \multirow{3}{*}{$\frac{\stackrel{\circ}{\Xi}}{\tilde{a}}$} \\
\hline & & \multicolumn{2}{|c|}{ yes } & \multicolumn{2}{|c|}{ sometimes } & \multicolumn{2}{|c|}{ No } & & & & \\
\hline & & 氞 & $\%$ & 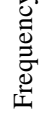 & $\%$ & 岂 & $\%$ & & & & \\
\hline 1 & $\begin{array}{l}\text { He helps groups } \\
\text { supervisee to take } \\
\text { advantage } \\
\text { electronic supervision } \\
\text { services in the school } \\
\text { field }\end{array}$ & 48 & 61.5 & 28 & 35.9 & 2 & 2.6 & 202 & 2.6 & 86.3 & 7 \\
\hline 2 & $\begin{array}{l}\text { He prepares the } \\
\text { training material that } \\
\text { helps their supervisee } \\
\text { groups for electronic } \\
\text { supervision }\end{array}$ & 53 & 67.9 & 24 & 30.8 & 1 & 1.3 & 208 & 2.7 & 88.9 & 6 \\
\hline 3 & $\begin{array}{l}\text { He adheres to the } \\
\text { necessary skills for } \\
\text { electronic supervision }\end{array}$ & 43 & 55.1 & 31 & 39.7 & 4 & 5.1 & 195 & 2.5 & 83.3 & 9 \\
\hline 4 & $\begin{array}{l}\text { He follows up the } \\
\text { supervisee groups by } \\
\text { electronic means }\end{array}$ & 56 & 71.8 & 22 & 28.2 & 0 & 0 & 212 & 2.7 & 90.6 & 3 \\
\hline 5 & $\begin{array}{l}\text { He encourages the } \\
\text { supervisee for } \\
\text { modern techniques in } \\
\text { order to continue } \\
\text { improvement in the } \\
\text { use of e-learning } \\
\text { system }\end{array}$ & 60 & 76.9 & 18 & 23.1 & 0 & 0 & 216 & 2.77 & 92.3 & 1 \\
\hline 6 & $\begin{array}{l}\text { He emphasizes the } \\
\text { importance of self- } \\
\text { censorship for their } \\
\text { supervisee groups }\end{array}$ & 48 & 61.5 & 28 & 35.9 & 2 & 2.6 & 202 & 2.6 & 86.3 & 7 \\
\hline 7 & $\begin{array}{l}\text { He identifies training } \\
\text { needs for supervisee } \\
\text { groups in light of the } \\
\text { electronic supervision } \\
\text { in school field }\end{array}$ & 57 & 73.1 & 20 & 25.6 & 1 & 1.3 & 212 & 2.7 & 90.6 & 3 \\
\hline 8 & $\begin{array}{l}\text { He contributes to } \\
\text { design of suitable } \\
\text { training programs for } \\
\text { electronic supervision }\end{array}$ & 42 & 53.8 & 29 & 37.2 & 7 & 9 & 191 & 2.4 & 81.6 & 10 \\
\hline 9 & 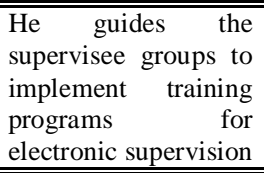 & 58 & 74.4 & 20 & 25.6 & 0 & 0 & 214 & 2.74 & 91.5 & 2 \\
\hline 10 & $\begin{array}{l}\text { He helps the } \\
\text { supervisee groups to } \\
\text { stabilize the training } \\
\text { institution }\end{array}$ & 53 & 67.9 & 25 & 32.1 & 0 & 0 & 209 & 2.68 & 89.3 & 5 \\
\hline
\end{tabular}




\begin{tabular}{|lr|}
\hline Egyptian Journal of Social Work (EJSW) & http://ejsw.journals.ekb.eg \\
ISSN: 2356-9204 & Vol 12, Issue 1, June 2021 \\
\hline
\end{tabular}

\begin{tabular}{|c|c|c|c|c|c|c|c|c|c|c|c|}
\hline 11 & $\begin{array}{l}\text { He defines criteria for } \\
\text { evaluating the } \\
\text { training process } \\
\text { considering } \\
\text { electronic supervision } \\
\text { in the school field }\end{array}$ & 41 & 52.6 & 31 & 39.7 & 6 & 7.7 & 191 & 2.4 & 81.6 & 10 \\
\hline \multicolumn{2}{|c|}{ Total } & 559 & 65.2 & 276 & 32.2 & 23 & 2.7 & 2252 & 2.6 & $\overline{87}$ & \\
\hline
\end{tabular}

This table shows the roles of the supervisor with supervisee groups during electronic supervision in the school field. These roles have a professional commitment of the supervisor to provide professional assistance to their supervisee groups such as:" He encourages the supervisee for modern techniques in order to continue improvement in the use of e-learning system", which came in the first ranking with percentage of $92.3 \%$, as for the second ranking "He guides the supervisee groups to implement training programs for electronic supervision" with percentage of $91.5 \%$, as for the third ranking "He follows up the supervisee groups by electronic means, and he identifies training needs for supervisee groups in light of the electronic supervision in school field" with percentage of $90.6 \%$, as for the fifth ranking "He helps the supervisee groups to stabilize the training institution" with percentage of $89.3 \%$, as for the sixth ranking "He prepares the training material that helps their supervisee groups for electronic supervision" with percentage of $88.9 \%$, as for the seventh ranking "He helps groups supervisee to take advantage of electronic supervision services in the school field, and he emphasizes the importance of self-censorship for their supervisee groups" with percentage of $86.3 \%$, as for the ninth ranking "He adheres to the necessary skills for electronic supervision" with percentage of $83.3 \%$, lastly the tenth ranking "He defines criteria for evaluating the training process in light of electronic supervision in the school field, and he contributes to design of suitable training programs for electronic supervision" with percentage of $81.6 \%$. 


\begin{tabular}{|lr||}
\hline Egyptian Journal of Social Work (EJSW) & http://ejsw.journals.ekb.eg \\
ISSN: 2356-9204 & Vol 12, Issue 1, June 2021 \\
\hline \hline
\end{tabular}

Table (7) shows the difficulties facing the supervisor with supervisee groups in electronic supervision in the school field $(\mathrm{N}=$ 78)

\begin{tabular}{|c|c|c|c|c|c|c|c|c|c|c|c|}
\hline \multirow[b]{3}{*}{$\mathrm{N}$} & \multirow[b]{3}{*}{ The difficulties } & \multicolumn{6}{|c|}{ Responses } & \multirow{3}{*}{ 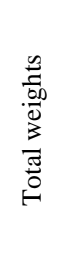 } & \multirow{3}{*}{ 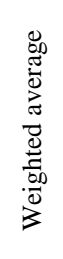 } & \multirow{3}{*}{ 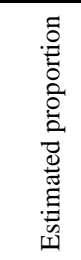 } & \multirow{3}{*}{ 章 } \\
\hline & & \multicolumn{2}{|c|}{ yes } & \multicolumn{2}{|c|}{ sometimes } & \multicolumn{2}{|c|}{ No } & & & & \\
\hline & & 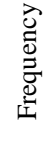 & $\%$ & 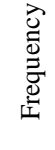 & $\%$ & 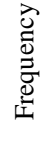 & $\%$ & & & & \\
\hline 1 & $\begin{array}{l}\text { the internet connection } \\
\text { slow }\end{array}$ & 58 & 74.4 & 13 & 16.7 & 7 & 9 & 207 & 2.65 & 88.5 & 1 \\
\hline 2 & $\begin{array}{l}\text { Lack of privacy, } \\
\text { especially when hacking } \\
\text { some electronic programs }\end{array}$ & 44 & 56.4 & 30 & 38.5 & 4 & 5.1 & 196 & 2.5 & 83.8 & 4 \\
\hline 3 & $\begin{array}{l}\text { Scarcity of statistics and } \\
\text { training information for } \\
\text { school field }\end{array}$ & 47 & 60.3 & 31 & 39.7 & 0 & 0 & 203 & 2.6 & 86.8 & 2 \\
\hline 4 & $\begin{array}{l}\text { Needy the qualification } \\
\text { suitable to use modern } \\
\text { applications in the } \\
\text { electronic supervision } \\
\text { process }\end{array}$ & 37 & 47.4 & 35 & 44.9 & 6 & 7.7 & 187 & 2.4 & 79.9 & 5 \\
\hline 5 & $\begin{array}{l}\text { The lack of a clear plan } \\
\text { for electronic supervision } \\
\text { in the school field }\end{array}$ & 45 & 57.7 & 29 & 37.2 & 4 & 5.1 & 197 & 2.5 & 84.2 & 3 \\
\hline & Total & 231 & 59.2 & 138 & 35.4 & 21 & 5.4 & 990 & 2.5 & & \\
\hline
\end{tabular}

This table displays the difficulties which face the supervisor with supervisee groups in light of electronic supervision in the school field such as: " the internet connection slow" that came in the first ranking with percentage of $88.5 \%$, as for the second ranking "Scarcity of statistics and training information for school field" with percentage of $86.8 \%$, as for the third ranking "The lack of a clear plan for electronic supervision in the school field" with percentage of $84.2 \%$, as for the fourth ranking "Lack of privacy, especially when hacking some electronic programs" with percentage of $83.8 \%$, as for the fifth ranking "Needy the qualification suitable to use modern applications in the electronic supervision process" with percentage of $79.9 \%$. 


\begin{tabular}{|lr||}
\hline Egyptian Journal of Social Work (EJSW) & http://ejsw.journals.ekb.eg \\
ISSN: 2356-9204 & Vol 12, Issue 1, June 2021 \\
\hline
\end{tabular}

Table (8) shows the suggestions for activating electronic supervision with supervisee groups in the school field $(N=78)$

\begin{tabular}{|c|c|c|c|c|c|c|c|c|c|c|c|}
\hline \multirow[b]{3}{*}{$\mathrm{N}$} & \multirow[b]{3}{*}{ The suggestions } & \multicolumn{6}{|c|}{ Responses } & \multirow{3}{*}{$\begin{array}{l}\frac{0}{0} \\
\frac{0}{000} \\
0 \\
3 \\
3 \\
0 \\
0 \\
0\end{array}$} & \multirow{3}{*}{ 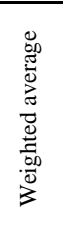 } & \multirow{3}{*}{ 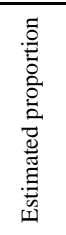 } & \multirow{3}{*}{ 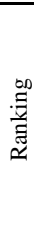 } \\
\hline & & \multicolumn{2}{|c|}{ yes } & \multicolumn{2}{|c|}{ sometimes } & \multicolumn{2}{|c|}{ No } & & & & \\
\hline & & 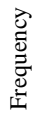 & $\%$ & 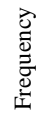 & $\%$ & 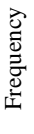 & $\%$ & & & & \\
\hline 1 & $\begin{array}{l}\text { Formulating a clear vision for } \\
\text { electronic supervision in the } \\
\text { school field that achieves } \\
\text { development professional skills } \\
\text { for supervisee groups }\end{array}$ & 58 & 74.4 & 20 & 25.6 & 0 & 0 & 214 & 2.7 & 91.5 & 5 \\
\hline 2 & $\begin{array}{l}\text { Holding training workshops that } \\
\text { achieve appropriate preparation } \\
\text { for electronic supervision }\end{array}$ & 64 & 82.1 & 14 & 17.9 & 0 & 0 & 220 & 2.8 & 94 & 1 \\
\hline 3 & $\begin{array}{l}\text { variety of supervisory techniques } \\
\text { to achieve the goals of electronic } \\
\text { supervision in the school field }\end{array}$ & 63 & 80.8 & 13 & 16.7 & 2 & 2.6 & 217 & 2.78 & 92.7 & 3 \\
\hline 4 & $\begin{array}{lcr}\text { Providing } & \text { the } & \text { necessary } \\
\text { technical } & \text { support } & \text { during } \\
\text { electronic } & \text { supervision } & \\
\end{array}$ & 60 & 76.9 & 13 & 16.7 & 5 & 6.4 & 211 & 2.7 & 90.2 & 7 \\
\hline 5 & \begin{tabular}{lcr} 
Providing & the & necessary \\
electronic & \multicolumn{2}{c}{ applications } \\
programs & for & electronic \\
supervision & &
\end{tabular} & 61 & 78.2 & 14 & 17.9 & 3 & 3.8 & 214 & 2.74 & 91.5 & 5 \\
\hline 6 & $\begin{array}{l}\text { Preparing electronic training } \\
\text { bags and providing them in the } \\
\text { electronic media }\end{array}$ & 54 & 69.2 & 24 & 30.8 & 0 & 0 & 210 & 2.7 & 89.7 & 8 \\
\hline 7 & $\begin{array}{lcr}\text { Designing } & \text { suitable } & \text { training } \\
\text { activities } & \text { for } & \text { electronic } \\
\text { supervision in the school field }\end{array}$ & 63 & 80.8 & 15 & 19.2 & 0 & 0 & 219 & 2.8 & 93.6 & 2 \\
\hline 8 & $\begin{array}{lrr}\text { Creating } & \text { a computerized } \\
\text { information } & \text { system that } \\
\text { facilitates coordination between } \\
\begin{array}{l}\text { academic and institutional } \\
\text { supervision }\end{array} & \\
\end{array}$ & 59 & 75.6 & 19 & 24.4 & 0 & 0 & 215 & 2.76 & 91.9 & 4 \\
\hline & Total & $\begin{array}{c}48 \\
2 \\
\end{array}$ & 77.2 & 132 & 21.2 & $\begin{array}{l}1 \\
0\end{array}$ & 1.6 & $\begin{array}{c}172 \\
0\end{array}$ & 2.76 & 91 & \\
\hline
\end{tabular}

This table reveals the suggestions for activating electronic supervision with supervisee groups in light of electronic supervision in the school field. These proposals can contribute to achieve the goals of professional practice such as: "Holding training workshops that achieve appropriate preparation for electronic supervision" It came in the first ranking with percentage of $94 \%$, as for the second ranking "Designing suitable training activities for electronic supervision in the school field" with percentage of $93.6 \%$, as for the third ranking "variety of supervisory techniques to achieve the goals of electronic supervision in the school field" with percentage of $92.7 \%$, as for the fourth ranking "Creating a computerized information system that facilitates coordination between academic and institutional supervision" with percentage of $91.9 \%$, as for the fifth ranking "Formulating a clear vision for electronic supervision in the school 
field that achieves development professional skills for supervisee groups, and providing the necessary electronic applications and programs for electronic supervision" with percentage of $91.5 \%$, as for the seventh ranking "Providing the necessary technical support during electronic supervision" with percentage of $90.2 \%$, and finally the eighth ranking "Preparing electronic training bags and providing them in the electronic media" with percentage of $89.7 \%$.

\section{Discussion Study Hypothesis}

Table (9) shows the correlation between types of training suitable in electronic supervision for male and female $(\mathrm{N}=78)$

\begin{tabular}{|c|c|c|c|c|}
\hline \multicolumn{2}{|c|}{ Gender Variable } & Spearman's rho & $\begin{array}{l}\text { Training is not } \\
\text { synchronized through } \\
\text { the World Wide Web }\end{array}$ & $\begin{array}{l}\text { Mixed training } \\
\text { between synchronous } \\
\text { and not synchronous }\end{array}$ \\
\hline \multirow{3}{*}{ male } & \multirow{6}{*}{$\begin{array}{l}\text { Synchronous } \\
\text { training through } \\
\text { the World Wide } \\
\text { Web }\end{array}$} & $\begin{array}{l}\text { Correlation } \\
\text { Coefficient }\end{array}$ & -.317 & $.645^{* *}$ \\
\hline & & Sig. & .140 & .001 \\
\hline & & $\mathrm{N}$ & 23 & 23 \\
\hline \multirow{3}{*}{ female } & & $\begin{array}{l}\text { Correlation } \\
\text { Coefficient } \\
\end{array}$ & .227 & $.322 *$ \\
\hline & & Sig. & .095 & .016 \\
\hline & & $\overline{\mathrm{N}}$ & $\overline{55}$ & $\overline{55}$ \\
\hline
\end{tabular}

The above-mentioned table shows that there is a statistically significant difference between males and females because the males indicted moderate negative correlation, but the females elucidate low positive correlation between Synchronous training through the World Wide Web and Training is not synchronized through the World Wide Web.

While it is found that males and the females indicted moderate positive correlation between synchronous training through the World Wide Web and mixed training between synchronous and not synchronous. 


\begin{tabular}{|lc||}
\hline Egyptian Journal of Social Work (EJSW) & http://ejsw.journals.ekb.eg \\
ISSN: 2356-9204 & Vol 12, Issue 1, June 2021 \\
\hline
\end{tabular}

Table (10) shows the correlation between the roles of the supervisor with supervisee groups and the tools for electronic supervision in the school field $(N=78)$

\begin{tabular}{|c|c|c|c|c|c|c|}
\hline Roles & 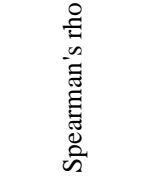 & 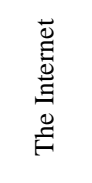 & 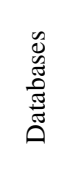 & 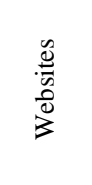 & 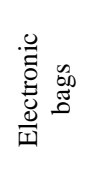 & 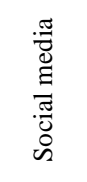 \\
\hline \multirow{2}{*}{$\begin{array}{l}\text { He helps groups supervisee to take } \\
\text { advantage of electronic supervision } \\
\text { services in the school field }\end{array}$} & $\begin{array}{l}\text { Correlation } \\
\text { Coefficient }\end{array}$ & $.397 * *$ & .017 & .167 & .116 & .138 \\
\hline & Sig. & .000 & .881 & .144 & .312 & .230 \\
\hline \multirow{2}{*}{$\begin{array}{l}\text { He prepares the training material that } \\
\text { helps their supervisee groups for } \\
\text { electronic supervision }\end{array}$} & $\begin{array}{l}\text { Correlation } \\
\text { Coefficient } \\
\end{array}$ & $.417 * *$ & -.096 & .200 & $.411 * *$ & .180 \\
\hline & Sig. & .000 & .406 & .079 & .000 & .115 \\
\hline \multirow{2}{*}{$\begin{array}{l}\text { He adheres to the necessary skills for } \\
\text { electronic supervision }\end{array}$} & $\begin{array}{l}\text { Correlation } \\
\text { Coefficient }\end{array}$ & $.496 * *$ & .031 & $.302 * *$ & .190 & .073 \\
\hline & Sig. & 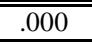 & .784 & .007 & .095 & .526 \\
\hline \multirow{2}{*}{$\begin{array}{l}\text { He follows up the supervisee groups by } \\
\text { electronic means }\end{array}$} & $\begin{array}{l}\text { Correlation } \\
\text { Coefficient } \\
\end{array}$ & $.324 * *$ & .143 & .214 & .180 & $.227 *$ \\
\hline & Sig. & .004 & .212 & .060 & .115 & .046 \\
\hline \multirow{2}{*}{$\begin{array}{l}\text { He encourages the supervisee for modern } \\
\text { techniques in order to continuous } \\
\text { improvement in the use of e-learning } \\
\text { system }\end{array}$} & $\begin{array}{l}\text { Correlation } \\
\text { Coefficient }\end{array}$ & .005 & .049 & $-.132-$ & $-.050-$ & $.299 * *$ \\
\hline & Sig. & .967 & .669 & .251 & .663 & .008 \\
\hline \multirow[t]{2}{*}{$\begin{array}{l}\text { He emphasizes the importance of self- } \\
\text { censorship for their supervisee groups }\end{array}$} & $\begin{array}{l}\text { Correlation } \\
\text { Coefficient } \\
\end{array}$ & $.375^{* *}$ & $.047-$ & .138 & $.323 * *$ & .150 \\
\hline & Sig. & .001 & $\begin{array}{l}.686 \\
\end{array}$ & .227 & .004 & .189 \\
\hline \multirow{2}{*}{$\begin{array}{l}\text { He identifies training needs for } \\
\text { supervisee groups in light of the } \\
\text { electronic supervision in school field }\end{array}$} & $\begin{array}{l}\text { Correlation } \\
\text { Coefficient }\end{array}$ & $.441 * *$ & .119 & $.246^{*}$ & $.415^{* * *}$ & $.261 *$ \\
\hline & Sig. & ב.000 & .301 & ב.030 & .000 & .021 \\
\hline \multirow{2}{*}{$\begin{array}{l}\text { He contributes to design of suitable } \\
\text { training programs for electronic } \\
\text { supervision }\end{array}$} & $\begin{array}{l}\text { Correlation } \\
\text { Coefficient } \\
\end{array}$ & $.381 * *$ & .015 & .137 & $.284 *$ & $.235^{*}$ \\
\hline & Sig. & .001 & .897 & .232 & .012 & .039 \\
\hline \multirow{2}{*}{$\begin{array}{l}\text { He guides the supervisee groups to } \\
\text { implement training programs for } \\
\text { electronic supervision }\end{array}$} & $\begin{array}{l}\text { Correlation } \\
\text { Coefficient } \\
\end{array}$ & $.562 * *$ & $-\overline{1}$ & $.353 * *$ & $.289 *$ & .108 \\
\hline & Sig. & ".000 & $\begin{array}{c}.301 \\
\end{array}$ & $\begin{array}{l}.002 \\
\end{array}$ & $\begin{array}{l}.010 \\
\end{array}$ & ב.347 \\
\hline \multirow{2}{*}{$\begin{array}{l}\text { He helps the supervisee groups to } \\
\text { stabilize the training institution }\end{array}$} & $\begin{array}{l}\text { Correlation } \\
\text { Coefficient } \\
\end{array}$ & $.586^{* *}$ & .078 & $.429 * *$ & $.470 * *$ & .180 \\
\hline & Sig. & .000 & .499 & .000 & .000 & .115 \\
\hline \multirow{2}{*}{$\begin{array}{l}\text { He defines criteria for evaluating the } \\
\text { training process in light of electronic } \\
\text { supervision in the school field }\end{array}$} & $\begin{array}{l}\text { Correlation } \\
\text { Coefficient } \\
\end{array}$ & $.262 *$ & .121 & .088 & .172 & .060 \\
\hline & Sig. & .021 & .290 & .444 & .132 & .599 \\
\hline
\end{tabular}

The above-mentioned table shows that there is a statistically significant correlation between the roles of the supervisor with supervisee groups and the tools for electronic supervision in the school field because there is a moderate positive correlation between 
the role: He helps groups supervisee to take advantage of electronic supervision services in the school field and the tool: the internet, employed in supervisory work. Also, we found moderate positive correlation between the role: He prepares the training material that helps their supervisee groups for electronic supervision and the tools: the internet, employed in supervisory work and electronic bags that are prepared by a computer programs giving specific information about a specific topic. In addition, we found moderate positive correlation between the role: He adheres to the necessary skills for electronic supervision and the tools: The internet, employed in supervisory work and Websites, which are electronic pages for obtaining information in training field. Likewise, there is a moderate positive correlation between the role: He follows up the supervisee groups by electronic means and the tool: The Internet, employed in supervisory work, and there is a low positive correlation with another tool: Social media (WhatsApp - Twitter - Instagram - Snapchat - ... etc.). Similarly, there is a moderate positive correlation between the role: He encourages the supervisee for modern techniques to continue improvement in the use of e-learning system and the tool: Social media (WhatsApp - Twitter - Instagram - Snapchat - ... etc.). However, there is a moderate positive correlation between the role: $\mathrm{He}$ emphasizes the importance of self-censorship for their supervisee groups and the tools: The Internet, employed in supervisory work and electronic bags that are prepared by a computer programs which specific information about a specific topic. Also, there is a moderate positive correlation between the role: He identifies training needs for supervisee groups in light of the electronic supervision in school field and the tools: The Internet, = employed in supervisory work, electronic bags that are prepared by a computer program about a specific topic and Social media (WhatsApp - Twitter - Instagram Snapchat - ... etc.). Furthermore, there is also a moderate positive correlation between the role: He contributes to design of suitable training programs for electronic supervision and the tools: The Internet, employed in supervisory work and Electronic bags that are prepared by a computer program which gives specific information about a specific topic. Moreover, there is a moderate positive correlation between the role: He guides the supervisee groups to implement training programs for electronic supervision and the tools: Websites, which are electronic pages for obtaining information in training field and electronic bags that are prepared by a computer 
programs which specific information about a specific topic. Moreover, there is a moderate positive correlation between the role: He helps the supervisee groups to stabilize the training institution and the tools: The Internet, employed in supervisory work, Websites, which are electronic pages for obtaining information in training field and electronic bags that are prepared by a computer program that provides specific information about a specific topic. Also, we found a moderate positive correlation between the role: He defines criteria for evaluating the training process considering electronic supervision in the school field and the tool: The Internet, employed in supervisory work.

Finally, these results show that the using the tools for electronic supervision is not enough to perform the professional roles. This correlates with the new experience for the nature of the supervisory work during coronavirus pandemic (COVID-19). Therefore, we should work to activate the electronic supervision because it is better in the case of Corona.

\section{Discussion}

The study focuses on the importance of electronic supervision in the school field, so the supervisor should use the types of training suitable for electronic supervision in the school field. This requires using variety of tools for electronic supervision in the school field such as social media, databases that facilitate access to training data, and electronic bags that are prepared by computer programs which give specific information about a specific topic.

The supervision process requires many roles to be successful; thus, the supervisor must perform theirs such as encouraging the supervisee to use modern techniques in order to achieve continuous improvement in the use of e-learning system, guiding the supervisee groups to implement training programs for electronic supervision, following up the supervisee groups by electronic means, and identifying s training needs for supervisee groups in light of the electronic supervision in school field, helping the supervisee groups to stabilize the training institution, preparing the training material that helps their supervisee groups in electronic supervision. Moreover, the supervisor faced many difficulties with supervisee groups in light of electronic supervision in the school field which must be overcame in order to achieve goals from electronic supervision such as the slow internet connection, scarcity of statistics and training information for school field, the lack of a clear plan for electronic supervision in the school field, lack of privacy, especially when hacking some electronic programs, the need 
for the suitable qualification to use modern applications in the electronic supervision process, absence of the description for supervisor and their supervisee roles in light of electronic supervision, and lack of suitable preparation in the school environment to apply electronic supervision, lack of clarity for the training objectives related to electronic supervision in the school field, weak preparation of their supervisee groups for electronic supervision, weak cooperation for their supervisee groups during the implementation of the required training activities.

\section{Further study also tends to:}

- Describe the role of supervisor with supervisee groups in light of electronic supervision in the school field.

- Prepare a comprehensive training program in the school field that depends on employing technological means.

- Orientate the electronic supervision in social work that benefits the quality of the supervisory process.

\section{recommendations:}

- The need to examine the role of different types of training suitable for electronic supervision in the school field.

- The need for coordination between training institutions in the school field to create a working system of electronic supervision.

- The need to pursue scientific research focused on professional requirements of electronic supervision, mechanisms for activating electronic supervision, and electronic supervision skills.

\section{Conclusion:}

Electronic supervision must be activated with supervisee groups in the school field through holding training workshops that achieve appropriate preparation for electronic supervision, designing suitable training activities for electronic supervision in the school field, variety of supervisory techniques to achieve the goals of electronic supervision in the school field, creating a computerized information system that facilitates coordination between academic and institutional supervision, formulating a clear vision for electronic supervision in the school field that achieves development professional skills for supervisee groups, and providing the necessary electronic applications and programs for electronic supervision, providing the necessary technical support during electronic supervision, preparing electronic training bags and providing them in the electronic media, and creating an electronic platform to facilitate electronic supervision process in the school field. 


\section{References:}

Al-Azamat, M. H. (2020). The degree practicing the educational supervisors in the First Zarqa Education Directorate for electronic supervision, its obstacles and requirements to development from their point of view. Journal of Educational and Psychological Sciences, 4(9), pp. 1- 20. Retrieved from http://ezproxysrv.squ.edu.om:2072/eds/pdfviewer/pdfviewer?vid=0\&sid $=0 f e 09 b 5 f-a a 03-4949-a 5 f f-0 f e 6 a 4 a 22 b 24 \% 40$ sessionmgr4006

Al-Daihani, S. G., Al-Khazzi, F. A., \& Al-Jadi, A. Y. (2016). The role of electronic supervision in achieving professional development for teachers in general education schools from the point of view department heads in Kuwait. Journal of Gulf and Arabian Peninsula Studies, 42(163), pp. 24-346. Retrieved from http://ezproxysrv.squ.edu.om:2072/eds/detail/detail?vid=0\&sid=d4b011 0c-b6c9-4db7-9803-667fe6331049\%40sdc-vsessmgr02\&bdata=JnNpdGU9ZWRzLWxpdmUmc2NvcGU9c210ZQ\%3 $\mathrm{d} \% 3 \mathrm{~d} \# \mathrm{AN}=120149884 \& \mathrm{db}=\mathrm{awr}$

Beddoe, L. (2016). Challenges in Professional Supervision : Current Themes and Models for Practice. London: Jessica Kingsley Publishers. Retrieved from

http://ezproxysrv.squ.edu.om:2072/eds/detail/detail? vid=1\&sid=7dd68d 78-41a3-4f54-ae36-

53d7c9ca2586\%40sessionmgr4006\&bdata=JnNpdGU9ZWRzLWxpdm Umc2NvcGU9c210ZQ\%3d\%3d\#AN=1231625\&db=nlebk

Fareez, M. (2019). Narrative tools in social work supervision: The supervisor life certificate and supervisee's journey tools. International Journal of Narrative Therapy \& Community Work, 4, pp. 64-73. Retrieved from http://ezproxysrv.squ.edu.om:2072/eds/detail/detail?vid=0\&sid=898144 58-9ff3-4b0c-9ea4-1 ea4c4d38c07\%40sdc-vsessmgr02\&bdata $=$ JnNpdGU9ZWRzLWxpdmUmc2NvcGU9c210ZQ\%3 d\%3d\#AN=edsihc.846743817237308\&db=edsihc

fath albab, E. A. (2016). electronic training continuous as a mechanism for the quality of group work method. Journal of social work, 8, pp. 361 395. Retrieved from http://search.mandumah.com/Record/783325

Fisher, A. K., Simmons, C., \& Allen, S. C. (2019). Introducing BSW Students to Social Work Supervision Prior to Field. Advances in Social Work, 18(4), pp. 1085-1102. doi:10.18060/21556

Mohamed, J. A. (2020). The effectiveness of the proposed training program to give female students in social work the requirements of telephone counseling. Journal of Studies in Social Work and Human Sciences, 49. Retrieved from https://jsswh.journals.ekb.eg 
O'Donoghue, K., Wong Yuh Ju, P., \& Tsui, M.-s. (2018). Constructing an evidence-informed social work supervision model. European Journal of Social Work, 21(3), pp. 348-358. doi:10.1080/13691457.2017.1341387

O'Donoghue, K., \& O'Donoghue, R. (2019). The Application of Ethics within Social Work Supervision: A Selected Literature and Research Review. Ethics \& Social Welfare, 13(4), pp. 340-360. Retrieved from http://ezproxysrv.squ.edu.om:2145/eds/detail/detail?vid=0\&sid=ae501ed d-2d79-45ee-b482-2fc7b005ae03\%40pdc-vsessmgr01\&bdata=JnNpdGU9ZWRzLWxpdmUmc2NvcGU9c210ZQ\%3 $\mathrm{d} \% 3 \mathrm{~d} \# \mathrm{AN}=140311250 \& \mathrm{db}=\mathrm{edb}$

O'Donoghue, K., \& Tsui, M.-s. (2015). Social Work Supervision Research (1970-2010): The Way We Were and the Way Ahead. British Journal of Social Work, 45(2), pp. 616-633. doi:10.1093/bjsw/bct115

Rankine, M. (2019). The 'thinking aloud' process: a way forward in social work supervision. Reflective Practice, 20(1), pp. 97-110. doi:10.1080/14623943.2018.1564651

Reamer, F. G. (2019). Social Work Education in a Digital World: Technology Standards for Education and Practice. Journal of Social Work Education, 55(3), pp. 420-432. Retrieved from http://dx.doi.org/10.1080/10437797.2019.1567412

Ricciardelli , L. A., Nackerud, L., Quinn, A. E., Sewell, M., \& Casiano, B. (2020). Social media use, attitudes, and knowledge among social work students: Ethical implications for the social work profession. Social Sciences \& Humanities Open, 2(1). doi:10.1016/j.ssaho.2019.100008

Tsui, M.-S. (2005). Social work supervision: contexts and concepts. Thousand Oaks , California: Sage Publications. Retrieved from http://ezproxysrv.squ.edu.om:2145/eds/detail/detail?vid=1\&sid=e8776f7 6-fa72-40f0-bb5c-ba0c58c91847\%40pdc-vsessmgr03\&bdata=JnNpdGU9ZWRzLWxpdmUmc2NvcGU9c210ZQ\%3 $\mathrm{d} \% 3 \mathrm{~d} \# \mathrm{AN}=467203 \& \mathrm{db}=$ nlebk 
